\title{
Rapamycin Inhibits Vascular Smooth Muscle Cell Migration
}

\author{
Michael Poon, Steven O. Marx, Richard Gallo, Juan José Badimon, Mark B. Taubman, and Andrew R. Marks \\ Laboratory of Molecular Cardiology, Cardiovascular Institute, Department of Medicine, Mount Sinai School of Medicine, New York \\ 10029
}

\begin{abstract}
Abnormal vascular smooth muscle cell (SMC) proliferation and migration contribute to the development of restenosis after percutaneous transluminal coronary angioplasty and accelerated arteriopathy after cardiac transplantation. Previously, we reported that the macrolide antibiotic rapamycin, but not the related compound FK506, inhibits both human and rat aortic SMC proliferation in vitro by inhibiting cell cycle-dependent kinases and delaying phosphorylation of retinoblastoma protein (Marx, S.O., T. Jayaraman, L.O. Go, and A.R. Marks. 1995. Circ. Res. 362:801). In the present study the effects of rapamycin on SMC migration were assayed in vitro using a modified Boyden chamber and in vivo using a porcine aortic SMC explant model. Pretreatment with rapamycin $(2 \mathrm{ng} / \mathrm{ml})$ for $48 \mathrm{~h}$ inhibited PDGFinduced migration (PDGF BB homodimer; $20 \mathrm{ng} / \mathrm{ml}$ ) in cultured rat and human SMC $(n=10 ; P<0.0001)$, whereas FK506 had no significant effect on migration. Rapamycin administered orally ( $1 \mathrm{mg} / \mathrm{kg}$ per $\mathrm{d}$ for $7 \mathrm{~d}$ ) significantly inhibited porcine aortic SMC migration compared with control ( $n=15 ; P<0.0001)$. Thus, in addition to being a potent immunosuppressant and antiproliferative, rapamycin also inhibits SMC migration. (J. Clin. Invest. 1996. 98:22772283.) Key words: immunophilin • restenosis - atherosclerosis • FK506 • FKBP12
\end{abstract}

\section{Introduction}

Abnormal vascular smooth muscle cell $(\mathrm{SMC})^{1}$ proliferation and migration play major roles in the formation of atherosclerotic plaques, in the development of restenosis after percutaneous transluminal angioplasty (PTCA) and in accelerated arteriopathy after cardiac transplantation (1-5). In normal vessels, the majority of SMC reside in the media, where they are quiescent and possess a "contractile" phenotype $(1,6)$ characterized by the abundance of actin- and myosin-contain-

M. Poon and S.O. Marx contributed equally to this paper.

Address correspondence to Andrew R. Marks, Box 1269, Mount Sinai School of Medicine, One Gustave L. Levy Place, New York, NY 10029. Phone: 212-241-0309; FAX: 212-996-4498; E-mail: a_marks @smtplink.mssm.edu

Received for publication 28 June 1996 and accepted in revised form 13 September 1996.

1. Abbreviations used in this paper: FKBP, FK506 binding protein; GAP, Ras-GTPase-activating protein; PI-3', phosphatidylinositol3-OH; PLC, phospholipase C; SMC, smooth muscle cell; PTCA, percutaneous transluminal angioplasty.

J. Clin. Invest.

(C) The American Society for Clinical Investigation, Inc. 0021-9738/96/11/2277/07 \$2.00

Volume 98, Number 10, November 1996, 2277-2283 ing filaments. In disease states, SMC reenter the cell cycle, proliferate, and migrate from the media to the intima (1). PDGF is a potent chemoattractant for SMC (6-8) and is thought to play a major role in stimulating SMC migration in experimental models of vessel injury $(9,10)$. After vessel injury, intimal SMC demonstrate a synthetic phenotype, secreting extracellular matrix, proteases, growth factors, and cytokines that contribute to further proliferation and migration (1, $5,6)$.

Recently, we reported that rapamycin, a macrolide antibiotic, inhibited both human and rat SMC proliferation by blocking cell cycle progression at the G1/S transition (11). This inhibition of cell proliferation was associated with decreases in cell cycle kinase activity and a reduction in the phosphorylation of retinoblastoma protein. We demonstrated that the antiproliferative properties of rapamycin were mediated through binding to the cytosolic receptor, FK506 binding protein (FKBP12) (11). FKBP12 is ubiquitously and abundantly expressed in many cells and tissues and is highly conserved throughout eukaryotic phylogeny (12-16). FKBPs catalyze the cis-trans isomerization of peptidyl-prolyl amide bonds of peptides; both rapamycin and FK506 inhibit this rotamase activity. However, the inhibition of rotamase activity is not responsible for the immunosuppressive effects of these agents (17).

In the present study, we demonstrate that rapamycin, but not FK506, blocks rat, porcine, and human SMC migration. The inhibitory effects on migration are competed by molar excesses of FK506, indicating that the effect is mediated through binding to the cytosolic receptor, FKBP12. In rat aortic SMC, the inhibition of rapamycin of both proliferation and migration is mediated through a novel form of FKBP12 which contains three amino acid substitutions compared with the human FKBP12, including a serine substitution for a highly conserved proline at residue 10 . The present data indicate that a target of the rapamycin-FKBP12 complex or a downstream effector molecule functions as a critical regulator of SMC migration.

\section{Methods}

Reagents. Rapamycin was a gift from Dr. Suren Sehgal (WyethAyerst Laboratories, Princeton, NJ), FK506 was from Fujisawa (Deerfield, IL), recombinant human PDGF-BB was from Cal Biochem (Stanford, CA).

Cell culture. Rat aortic SMC (passages 8-11) were cultured in DME plus $20 \%$ FCS (Gibco, Grand Island, NY), $100 \mathrm{U} / \mathrm{ml}$ penicillin, and $100 \mu \mathrm{g} / \mathrm{ml}$ streptomycin as previously described $(11,18)$. The medium was changed every $48 \mathrm{~h}$, and cells were passaged at $\sim 75 \%$ confluence. Human aortic SMC (passages 3-5), were obtained from the ascending aorta at the time of cardiac transplantation. The adventitia and connective tissue were removed, the remaining arterial intima and media were cut into $1-\mathrm{cm}^{2}$ segments, and placed in culture dishes with collagenase and $15 \%$ FCS. Cells were grown in DME medium supplemented with $20 \%$ FCS, $100 \mathrm{U} / \mathrm{ml}$ penicillin, and $100 \mu \mathrm{g} / \mathrm{ml}$ streptomycin. Aortic SMC were serially passaged before reaching confluence. Cells were identified as smooth muscle by their typical 
appearance on light microscopy and by immunostaining with antismooth muscle $\alpha$-actin 1A4 (M851; Dako Inc., Carpenteria, CA).

Smooth muscle cell migration assay. Migration was measured using a 48-well chamber (modified Boyden chamber) housing a polycarbonate filter with 8- $\mu$ m pores (Nucleopore, Cabin John, MD) (19). Each membrane was coated with $0.1 \mathrm{mg} / \mathrm{ml}$ of collagen (Vitrogen $100^{\circledR}$; Centrix, Santa Clara, CA) in $0.2 \mathrm{M}$ acetic acid for $24 \mathrm{~h}$ before each chemotactic assay. For each assay, $27 \mu \mathrm{l}$ of PDGF-BB (20 ng/ $\mathrm{ml}$ ) in DME plus $0.2 \%$ BSA were loaded in quadruplicate wells in the bottom chamber. BSA ( $0.2 \%$ in DME without PDGF) was used as a negative control. SMC were grown to $\sim 30 \%$ confluence. Rapamycin or FK506 was then added directly to the culture media of some plates, control was without drug. After $48 \mathrm{~h}$ of incubation, cells were trypsinized, washed three times with PBS, and counted with a hemocytometer. Cell viability was determined by trypan blue exclusion. To examine the acute effect of rapamycin on SMC migration, rapamycin $(100 \mathrm{ng} / \mathrm{ml})$ was added directly to the upper or lower chamber without pretreatment. SMC grown in the absence of rapamycin were loaded in the upper chamber.

Equal numbers of cells $\left(2 \times 10^{5} / \mathrm{ml}\right)$ in $50 \mu \mathrm{l}$ were placed in the top chamber. After $6 \mathrm{~h}$ of incubation in $5 \% \mathrm{CO}_{2}$ at $37^{\circ} \mathrm{C}$, nonmigrating cells were scraped from the upper surface of the filter. Cells on the lower surface were fixed with methanol and stained with DiffQuik (Baxter Healthcare Co., Miami, FL). The number of SMC on the lower surface of the filter was determined microscropically by counting five high power $(\times 400)$ fields of constant area per well. Values are expressed as the percentage of cells migrating in response to PDGF-BB after subtraction of the negative control (DME + BSA). Experiments were performed at least twice using quadruplicate wells. Statistical significance was determined using the unpaired Student's $t$ test $P<0.01$ was considered a significant result.

Northern analyses. Total RNA was prepared from SMC growing in $\log$ phase using the standard guanidinium-isothiocyanate lysis buffer and centrifugation through a cesium chloride cushion as described elsewhere (20). $20 \mu \mathrm{g}$ of total RNA was size fractionated on a $1 \%$ formaldehyde agarose gel, blotted to nitrocellulose, and probed with $\alpha{ }^{32} \mathrm{P}$-labeled FKBP12 cDNA randomly labeled to a specific activity of $10^{9} \mathrm{cpm} / \mu \mathrm{g}$. The FKBP12 cDNA probe contained the entire coding region of the rabbit FKBP12 (16). Hybridization was at $42^{\circ} \mathrm{C}$ overnight and final washing at $65^{\circ} \mathrm{C}$ in $0.2 \times \mathrm{SSC}$. Films were autoradiographed with a single intensifying screen at $-70^{\circ} \mathrm{C}$ for $48 \mathrm{~h}$. Ethidium bromide staining of the $28 \mathrm{~S}$ ribosomal RNA was used to ensure that equivalent amounts of RNA were loaded in each lane. Northern analyses were repeated at least three times with the same results, a representative blot is shown.

Immunoblots. SMC growing in log phase were washed twice with ice-cold PBS and lysates were prepared using modified RIPA buffer (50 mM Tris- $\mathrm{HCl}, \mathrm{pH} 7.4,250 \mathrm{mM} \mathrm{NaCl}, 5 \mathrm{mM}$ EDTA, $50 \mathrm{mM} \mathrm{NaF}$, $0.1 \mathrm{mM} \mathrm{Na}_{3} \mathrm{VO}_{4}, 0.5 \mathrm{mM}$ PMSF, $1 \mu \mathrm{g} / \mathrm{ml}$ aprotinin, $1 \mu \mathrm{g} / \mathrm{ml}$ leupeptin, $1 \%$ NP- $40,0.5 \%$ sodium deoxycholate, and $0.1 \%$ SDS). Cells were scraped off the bottom of the plates and lysates rocked for $1 \mathrm{~h}$ at $4^{\circ} \mathrm{C}$. Lysates were clarified by centrifugation on a table top centrifuge for $20 \mathrm{~min}$ at 14,000 at $4^{\circ} \mathrm{C}$. Protein concentration was measured using the Bradford reagent (Bio-Rad Laboratories, Richmond, CA) with BSA as a standard. Protein extracts $(50 \mu \mathrm{g})$ were size-fractionated on $15 \%$ SDS-polyacrylamide gels and transferred to nitrocellulose overnight at $45-60 \mathrm{~V}$. Filters were blocked in PBS containing $0.1 \%$ Tween 20 (PBS-T), and $5 \%$ dry milk for $1 \mathrm{~h}$ at $30^{\circ} \mathrm{C}$, followed by incubation overnight at $4^{\circ} \mathrm{C}$ with either an anti-FKBP12 antibody directed against the amino-terminus of FKBP12 (16) or against the carboxy terminus (1/1,000, gift from Dr. Greg Wiederrecht, Merck Research Laboratory). The filters were washed with PBS-T, then incubated with secondary antibody conjugated to peroxidase for $1 \mathrm{~h}$ at $4^{\circ} \mathrm{C}$ and washed; signals were detected using the chemiluminescence detection system (ECL; Bio-Rad) followed by exposure to Kodak XAR film.

Library screening. A rat aortic SMC oligo-dT primed cDNA library in $\lambda$ ZAPII was screened using a full-length rabbit FKBP12 cDNA that includes the entire coding region of FKBP12 as described previously (16). A total of $10^{6}$ recombinants were screened at high stringency (final wash was $0.1 \times \mathrm{SSC}$ at $65^{\circ} \mathrm{C}$ ). After tertiary screening, five FKBP12 cDNA clones were isolated. The sequence reported in this study was obtained from five independent cDNA clones using the dideoxy chain termination methodology (20).

Explant model. 15 adult Yorkshire albino pigs (body wt 30-35 $\mathrm{kg}$ ) were randomly assigned to receive either regular pig chow or pig chow plus rapamycin for $7 \mathrm{~d}$. Three animals received $1 \mathrm{mg} / \mathrm{kg}$ of rapamycin orally and four animals received $5 \mathrm{mg} / \mathrm{kg}$ for $7 \mathrm{~d}$. Animals were euthanized with $10 \mathrm{ml}$ of Sleepaway (26\% sodium pentobarbital, $10 \%$ isopropyl alcohol, $20 \%$ polyethelene glycol; Fort Dodge Laboratories, Fort Dodge, IA). The aortas were perfused in situ with ice-cold physiologic buffer at a pressure of $100 \mathrm{mmHg}$. The aortas were excised, adventitia and surrounding connective tissue were removed. Aortas were opened by a longitudinal cut and the intima as well as a thin portion of the subjacent media were removed. The media were divided into five $10 \times 10-\mathrm{mm}^{2}$ segments that were cut into multiple $2 \times 2-\mathrm{mm}^{2}$ segments and placed in 100-mm culture dishes containing $10 \mathrm{ml}$ of DMEM $+20 \%$ FBS. Culture media were changed every $3-4 \mathrm{~d}$. On days 5, 10, and 15, culture dishes were washed with PBS to remove cellular debris, trypsinized briefly with $1.5 \mathrm{ml}$ of trypsin, resuspended in $2 \mathrm{ml}$ of PBS, and cells were counted (eight times per dish) using a hemocytometer. The results are presented in Fig. 5 as mean values \pm standard error of the mean for eight determinations from each of eight control, and seven rapamycin-treated animals. Cell viability was assessed using the trypan blue exclusion method. Rapamycin levels in whole blood samples were determined by Wyeth-Ayerst Laboratories. Routine histologic examinations of the aortas to assess the effects if any of rapamycin on SMC morphology were performed using hematoxylin and eosin stained sections.

Adhesion assay. Rat aortic SMC were incubated either with or without $20 \mathrm{ng} / \mathrm{ml}$ of rapamycin in DMEM supplemented with $10 \%$ FBS for $72 \mathrm{~h}$. After $72 \mathrm{~h}$ cells were detached from the plates by brief trypsinization in $2 \mathrm{ml}$ of trypsin/EDTA, resuspended in $10 \mathrm{ml}$ DMEM $+10 \%$ FBS, and cell number was determined. There were fewer cells in the rapamycin treated samples compared with the control $(4.4 \times$ $10^{6}$ vs $8.8 \times 10^{6}$ ) due to the antiproliferative effect of rapamycin on smooth muscle cells (11). Four six-well culture plates were precoated with varying concentrations of collagen (from $1 \mu \mathrm{g} / \mathrm{ml}$ to $1,000 \mu \mathrm{g} / \mathrm{ml}$ of Vitrogen). Smooth muscle cells were resuspended in DMEM to give a final concentration of $2.0 \times 10^{5}$ cells $/ \mathrm{ml}$. $1 \mathrm{ml}$ of SMC was added to each well. After $2.5 \mathrm{~h}$, nonadherent cells were removed and the number of cells adhering to the bottom of the wells was determined by counting four separate fields of constant area per well. All experiments were performed in triplicate.

\section{Results}

Rapamycin as low as $2 \mathrm{ng} / \mathrm{ml}$ had a significant inhibitory effect $(P<0.0001)$ on PDGF-BB homodimer-induced rat aortic SMC migration (Fig. $1 A$ ). Similarly, rapamycin significantly inhibited PDGF-BB induced human SMC migration (Fig. $1 B$; $P<0.0001)$. The inhibition of migration was concentration dependent with an $\mathrm{IC}_{50}=2 \mathrm{ng} / \mathrm{ml}$ for both rat and human SMC. In contrast, FK506 (1-500 ng/ml) had no significant effect on migration in response to PDGF-BB (Fig. $1 A$ ). The inhibition of migration by rapamycin persisted for at least $72 \mathrm{~h}$ in the Boyden chamber assays. By $96 \mathrm{~h}$ cell viability was substantially decreased in both control and in rapamycin-treated cultures, preventing assessment of cellular migration. There was no difference in cell viability between the control, FK506, and rapamycin treated cells as assessed by trypan blue staining. No difference in morphology was observed comparing rat SMC from rapamycin-treated and untreated cultures (Fig. $1 C$ ). As previously described (11), rapamycin inhibited SMC proliferation, whereas FK506 had no effect (data not shown). However, 


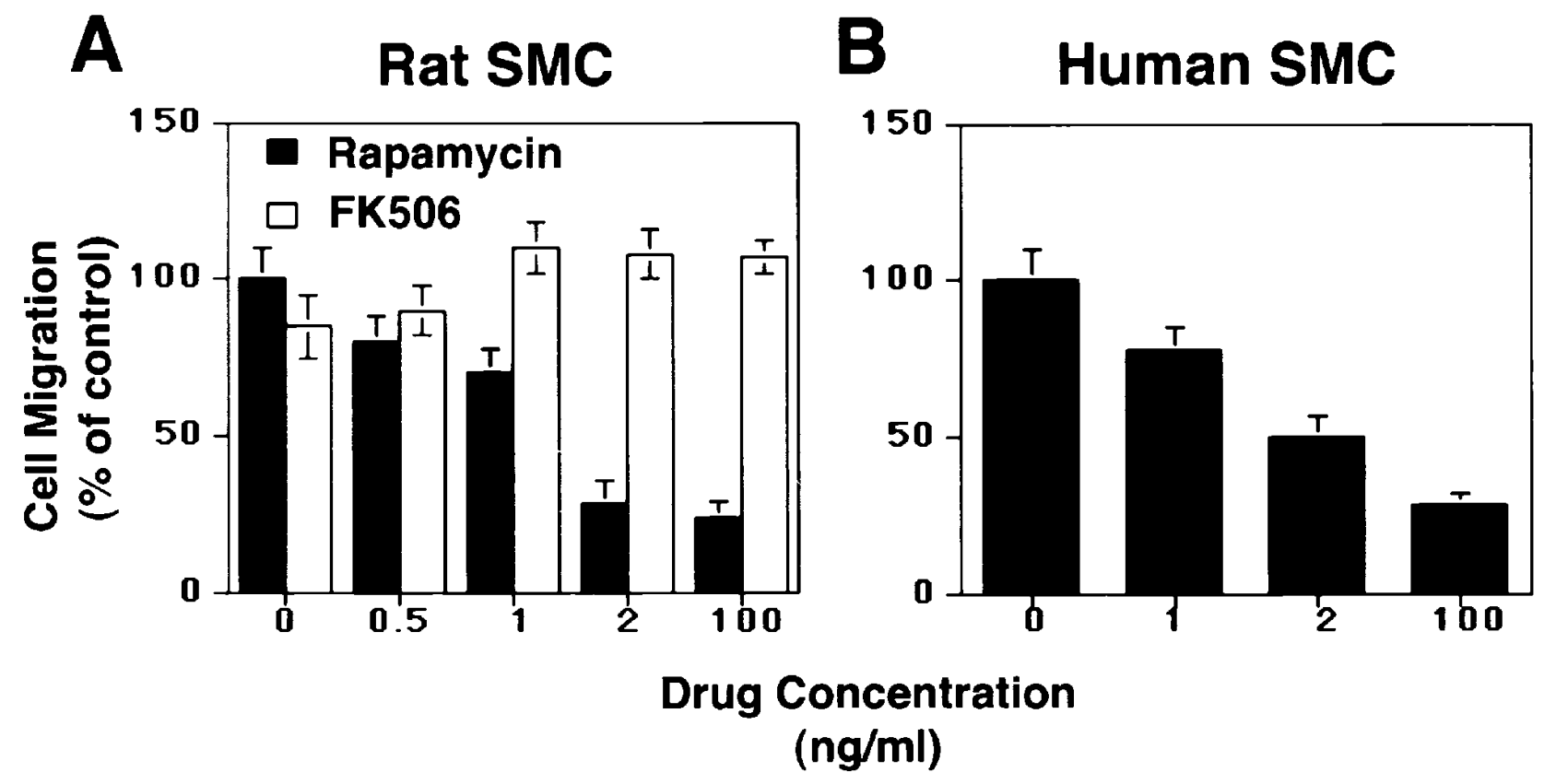

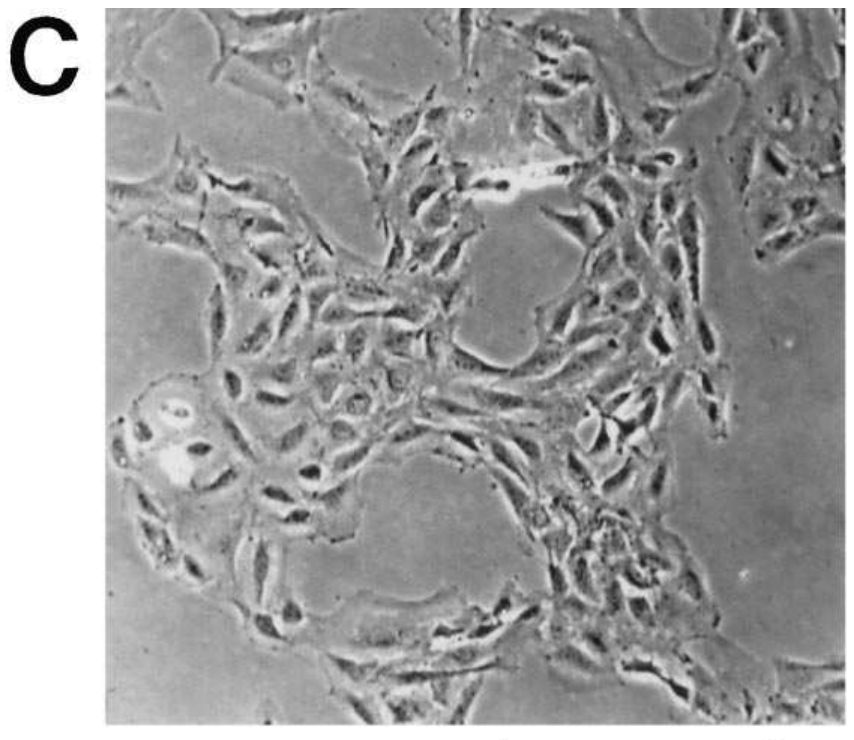

rapamycin treated

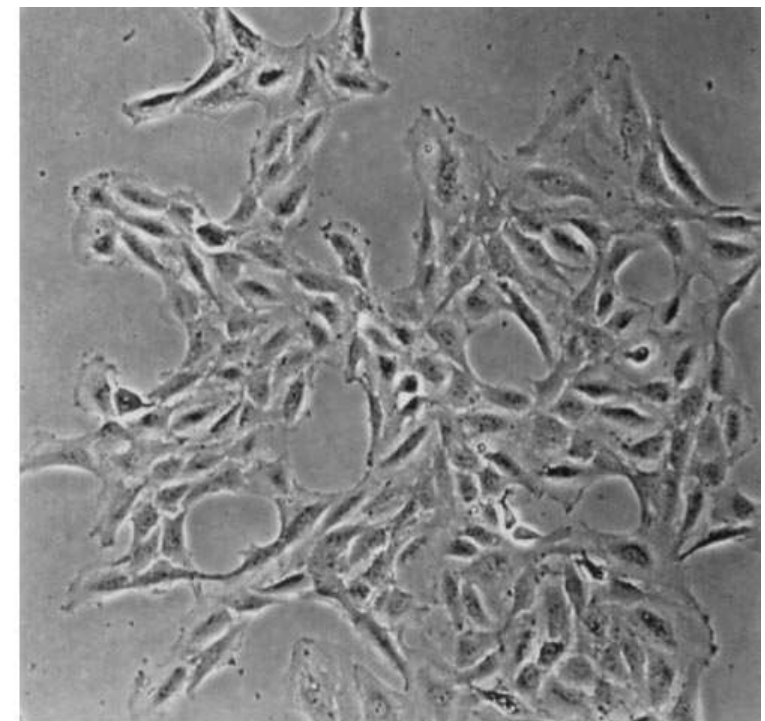

untreated

Figure 1. Rapamycin but not FK506 inhibits aortic smooth muscle cell migration. $(A)$ Rat aortic SMC were cultured with either rapamycin or FK506 for $48 \mathrm{~h}$ and then examined for chemotaxis to $20 \mathrm{ng} / \mathrm{ml}$ of PDGF-BB in a modified Boyden chamber. $P=0.01$ for control vs. $1 \mathrm{ng} / \mathrm{ml} \mathrm{ra-}$ pamycin, $P<0.0001$ for control vs. 2 and $100 \mathrm{ng} / \mathrm{ml}$ rapamycin. $(B)$ Similar experiments were performed using human aortic SMC cultured with rapamycin. $P<0.0001$ for each concentration of rapamycin compared with control. There is no significant difference between control and FK506-treated rat or human cells (not shown). The results represent mean values obtained from quadruplicate wells from each of two experiments. Error bars represent standard error of the mean. (C) Culturing with rapamycin had no effect on rat SMC morphology; compare control cells to cells cultured for $72 \mathrm{~h}$ with rapamycin $(20 \mathrm{ng} / \mathrm{ml})$.

equal numbers of cells were used in all migration assays. Thus the reduction in migration did not simply reflect a difference in cell number between control, FK506, and rapamycin treated cells.

Addition of rapamycin $(100 \mathrm{ng} / \mathrm{ml})$ to the cells immediately before loading into the upper Boyden chamber (Fig. 2), or incubation with rapamycin $(100 \mathrm{ng} / \mathrm{ml}$ ) for up to $6 \mathrm{~h}$ (data not shown) had no effect on migration. Similarly, rapamycin, when added together with PDGF to the lower chamber, had no effect on the ability of PDGF to attract normal SMC (Fig. 2). These results indicate that inhibition of SMC migration by rapamycin requires $>6 \mathrm{~h}$ exposure to rapamycin. The inhibition of migration of rat aortic SMC by rapamycin $(100 \mathrm{ng} / \mathrm{ml})$ was competitively inhibited by $80 \pm 10 \%$ by a 100 -fold molar ex- 


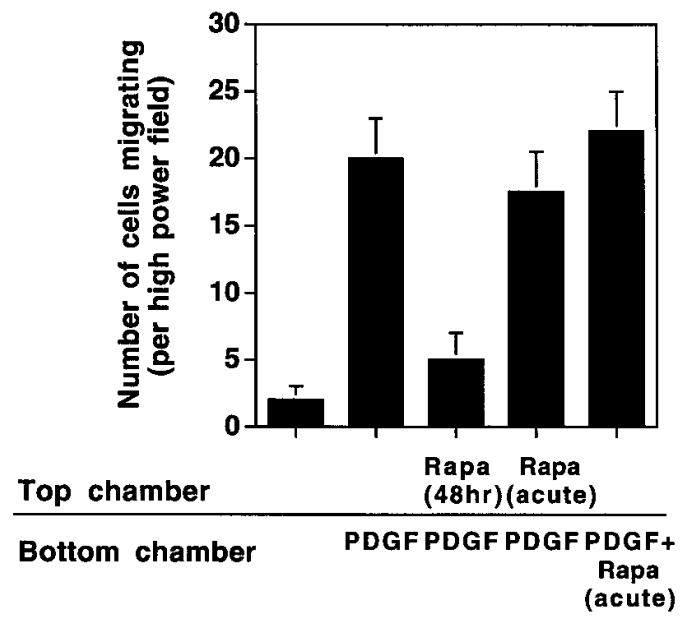

Figure 2. Inhibition of aortic smooth muscle migration requires prolonged exposure to rapamycin. Rat SMC added to the top chamber in the migration assay did not migrate when PDGF-BB was omitted from the bottom chamber (first bar). When PDGF-BB (PDGF, $20 \mathrm{ng} /$ $\mathrm{ml}$ ) was added to the bottom chamber, rat SMC migration was observed (second bar). Treatment of rat SMC with rapamycin (Rapa, $100 \mathrm{ng} / \mathrm{ml}$ ) for $48 \mathrm{~h}$ significantly inhibited migration (third bar, $P<$ $0.001)$. In contrast, acute administration of rapamycin $(100 \mathrm{ng} / \mathrm{ml})$ to the top (fourth bar) or bottom (fifth bar) chamber had no effect on migration. The $y$-axis shows the number of cells migrating onto the filter per high power field (see Methods for details).

cesses of FK506, indicating that the inhibition of migration by rapamycin was mediated by the binding to the immunophilin FKBP12, since both rapamycin and FK506 share the same cytosolic receptor.

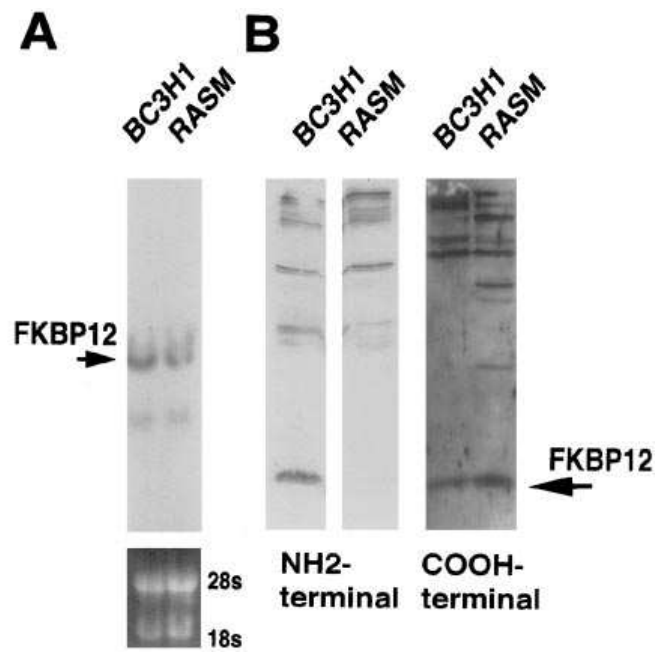

Figure 3. Analyses of FKBP12 mRNA and protein in rat SMC. $(A)$ Northern hybridization using a full-length FKBP12 cDNA shows equivalent levels of FKBP12 mRNA (1.5 kb) in a murine muscle cell line $(B C 3 H 1)$ and in rat aortic SMC $(R A S M)$. (B) Immunoblot analysis using an anti-FKBP12 antibody (16) that recognizes the aminoterminus of the human, rabbit, and murine FKBP12 shows no detectable FKBP12 protein in rat SMC, whereas an immunoblot using an anti-FKBP12 antibody directed at the carboxyl-terminus of FKBP12 shows a $12-\mathrm{kD}$ protein in rat SMC.
FKBP12 is ubiquitously expressed and highly conserved across species. However, immunoblotting with an antibody that recognizes the amino-terminus of the human, rabbit, and murine FKBP12 did not detect FKBP protein in rat aortic SMC (Fig. 3). In contrast, Northern hybridization using a fulllength FKBP12 cDNA revealed high levels of FKBP12 mRNA $(1.5 \mathrm{~kb})$ in rat aortic SMC (Fig. 3) and an antibody directed at the carboxyl-terminus of FKBP12 identified a $12-\mathrm{kD}$ protein in rat aortic SMC (Fig. 3). To determine the complete structure of the rat smooth muscle FKBP12, five FKBP12 cDNAs were isolated from a rat aortic SMC library and sequenced (Fig. 4). The rat FKBP12 encodes a 108-amino acid protein whose sequence is $95 \%$ identical to the human and rabbit form and $98 \%$ identical to the murine sequence. Notably, there is a serine for proline substitution at residue 10 in the middle of the epitope recognized by the amino-terminal FKBP12 antibody.

Rapamycin inhibits intimal thickening in rat aortas after mechanical or alloimmune injury (21) and reduces luminal narrowing following PTCA in porcine coronary arteries by 63\% (Gallo, R., A. Padurean, J.H. Chesebro, J.T. Fallon, V. Fuster, A.R. Marks, and J.J. Badimon, manuscript submitted for publication). The latter study showed further that the reduction in luminal narrowing after PTCA was due to inhibition of intimal SMC hyperplasia typically observed in the vessel wall after balloon injury. Reduction in intimal SMC hyperplasia in rapamycin-treated animals presumably reflects the fact that the drug causes a block in $\mathrm{G} 1$ to $\mathrm{S}$ progression in SMC (11). However, SMC migration is also an important component of the intimal thickening after PTCA. SMC have to migrate from the media into the intima to proliferate and cause luminal narrowing. To assess the in vivo effects of oral rapamycin on SMC migration we examined the ability of cells to migrate out of porcine aortic explants and establish cultures. SMC from control untreated animals began to migrate out of the explanted aortic tissue by day 5 and reached near-confluence on day 15 . In contrast, SMC from animals receiving $1 \mathrm{mg} /$ $\mathrm{kg}$ of rapamycin did not migrate out of the aortic tissue until day 10 , and by day 15 the number of cells was significantly reduced despite the fact that the only exposure to rapamycin for these cells had been in the intact animal (Fig. 5). SMC from animals treated with $5 \mathrm{mg} / \mathrm{kg}$ of rapamycin exhibited no migration even by day 15 after explant. Histological examination revealed no morphologic differences between SMC in control versus untreated animals, and trypan blue exclusion tests revealed no increase in cell death in SMC from rapamycin treated animals. Rapamycin levels in whole blood were $30 \pm 2 \mathrm{ng} / \mathrm{ml}$ and $85 \pm 5 \mathrm{ng} / \mathrm{ml}$ for the $1 \mathrm{mg} / \mathrm{kg}$ and $5 \mathrm{mg} / \mathrm{kg}$ dosing regimens, respectively. The concentration of $30 \pm 2 \mathrm{ng} / \mathrm{ml}$ is comparable to that observed in humans receiving rapamycin after renal transplant, whereas the concentration of $85 \pm 5 \mathrm{ng} / \mathrm{ml}$ would be considered above the recommended therapeutic levels. An assay was done to determine whether rapamycin affected the ability of SMC to bind to collagen. Control rat aortic SMC and cells pretreated with rapamycin using the conditions described above for the Boyden chamber assays were plated on collagen coated culture dishes in DMEM. At $2.5 \mathrm{~h}$ there were no significant differences between the rapamycin-treated and the control cells in terms of the number of SMC adhering to collagen-coated and the noncoated culture plates (control $55 \pm 3$, rapamycin $58 \pm 3 ; P=\mathrm{NS}$ ). These results suggest that rapamycin does not affect the ability of smooth muscle cells to adhere to collagen. 


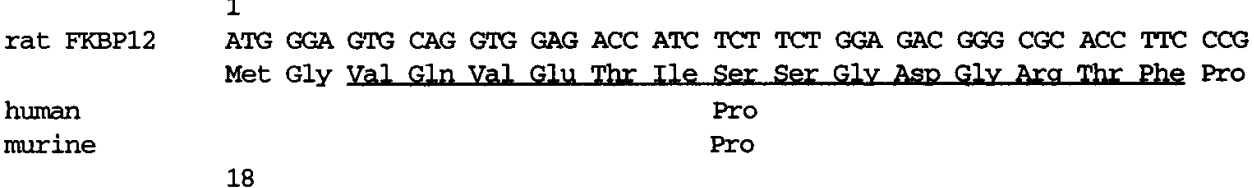

AAG CGC GGC CAG ACC TGC GTG GTA CAC TAC ACG GGG ATG CTT GAA GAT GGG Lys Arg Gly Gln Thr Cys Val Val His Tyr Thr Gly Met Leu Glu Asp Gly

35

AAG AAA TTT GAC TCC TCT CGG GAC AGA AAC AAG CCT TTT AAG TTT ACA CTA Lys Lys Phe Asp Ser Ser Arg Asp Arg Asn Lys Pro Phe Lys Phe Thr Leu Met

52

GGC AAG CAG GAG GTG ATC CGA GGC TGG GAA GAA GGG GTA GCC CAG ATG AGT Gly Lys Gln Glu Val Ile Arg Gly Trp Glu Glu Gly Val Ala Gln Met ser

69

GTG GGC CAG AGA GCC AAA CTG ATA ATC TCC CCA GAC TAT GCC TAT GGA GCC Val Gly Gln Arg Ala Lys Leu Ile Ile Ser Pro Asp Tyr Ala Tyr Gly Ala Thr

86
ACC GGG CAC CCA GGC ATC ATC
Thr Gly His Pro Gly Ile Ile
103
GAG CTT CTA AAA CTG GAA TGA
Glu Leu Leu Lys Leu Glu

Ser

Glu Leu Leu Lys Leu Glu
Figure 4. Comparison of the primary structure of the rat, human, and murine FKBP12. The cDNA and predicted amino acid sequence of the rat FKBP12 compared with human (rabbit is identical to human [16]) and murine FKBP12 (12). The open reading frame encodes a 108-amino acid protein that differs from the human and rabbit FKBP12 at three residues, and from the murine FKBP12 at two residues. The epitope recognized by the amino terminal antiFKBP12 antibody (16) is denoted by the underlined sequence. These sequence data are available from GenBank, BankIt67151, under accession number U69485.

\section{Discussion}

This study demonstrates that rapamycin inhibits rat, porcine, and human SMC migration. We have previously demonstrated that rapamycin has antiproliferative effects on rat and human aortic SMC mediated by binding to FKBP12 and inhibiting cell

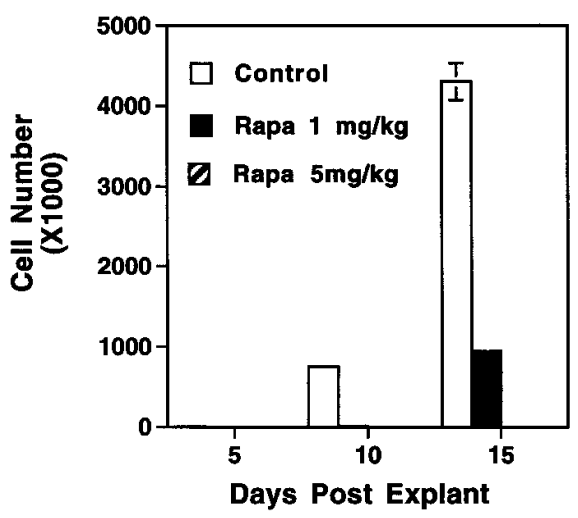

Figure 5. In vivo administration of oral rapamycin inhibits SMC migratory potential. Migratory potential of SMC was examined by determining the ability of cells to move out from porcine aortic tissue samples taken from animals treated with rapamycin compared to control (see Methods for experimental detail). SMC migrating out from the explanted tissue from both control and rapamycin $(1 \mathrm{mg} / \mathrm{kg}$ per day)-treated animals were able to grow in culture. However, there was a 5-d delay in migration exhibited by SMC in the treated versus control animals resulting in significantly larger numbers of cells (Cell Number) in explant cultures from control animals. No SMC migration was observed in aortas from animals treated with the higher concentration of rapamycin $(5 \mathrm{mg} / \mathrm{kg})$, even by day 15 after explant. When the standard deviation is small no error bars are seen. cycle kinases and delaying phosphorylation of retinoblastoma protein (11). The inhibitory effects of rapamycin on SMC migration are also mediated by its binding to FKBP12. Recently, a mammalian target of the rapamycin-FKBP12 complex (mTOR) has been identified $(22,23)$. While the immediate downstream target of mTOR has not been identified, a common theme in many cell types is that rapamycin-FKBP12 inhibits p70 S6 kinase $(24,25)$, cell cycle kinases, hyperphosphorylation of $\mathrm{Rb}$, and up-regulates the cyclin inhibitor p27 (26). Whether the antimigratory actions of rapamycin-FKBP12 in SMC involve any of these signaling molecules remains unproven. However, the present study suggests that rapamycin can be used as a "molecular probe" to dissect signaling pathways regulating SMC migration in much the same way as the drug is being used to gain insight into mechanisms controlling cell growth.

In the present study acute administration of rapamycin had no effect on the rat aortic SMC migration, suggesting that longer exposure to rapamycin $(>6 \mathrm{~h})$ is required. Cellular locomotion required for migration is mediated by the coordinated changes in the polymerization and depolymerization of actin containing microfilaments $(27,28)$, although the mechanism regulating these changes remain uncertain. Recently, it has been reported that recruitment of signaling proteins including the PDGF receptor and phospholipase C (PLC) $\gamma$ and phosphatidylinositol-3-OH (PI-3') kinase association with the PDGF receptor triggers migration (29). Upon stimulation by PDGF, the PDGF receptor- $\beta$ autophosphorylates and forms a complex with src homology 2-domain containing proteins such as phosphatidylinositol-specific PLC- $\gamma$, Ras-GTPase-activating protein (GAP), and PI-3' kinase (29). The association of activated PDGF receptor- $\beta$ with either PLC- $\gamma$ or PI-3' kinase promotes migration, whereas association with GAP retards 
migration in response to PDGF- $\beta$ (29). PLC- $\gamma$ and PI-3' kinase have been shown to modulate actin assembly (30). Both calcium and polyphosphoinositides have been proposed to regulate actin formation (32). A recent study demonstrated that activation of calcium/calmodulin-dependent protein kinase II (CaM kinase II) is a critical event for the migration of SMC. Inhibiting CaM kinase II blocked migration by $>90 \%$, whereas the inhibition of protein kinase $\mathrm{C}$ activation had no significant effect on migration (28). Although mTOR has no apparent PI-3' kinase activity, its counterpart in yeast, TOR, is a PI-3' kinase homologue (32).

Moreover, FKBP12 is physically associated with the type I TGF- $\beta$ receptor, suggesting that FKBP12 may have a direct role in modulating signal transduction mediated by growth factor receptors (33). These observations suggest that one mechanism whereby the rapamycin-FKBP12 complex could block SMC migration might be via inhibition of a growth factormediated pathway, possibly one that links migration to cell cycle progression.

The morphology of SMC from treated and untreated cultures (Fig. $1 C$ ) and tissue sections was indistinguishable, suggesting that rapamycin does not appear to have an effect on the cytoskeletal components that have been associated with migration. Moreover, rapamycin does not alter the ability of SMC to bind collagen, suggesting that the antimigratory effects of the drug are not due to an inability to interact with the extracellular matrix.

The immunosuppressant drugs rapamycin and FK506 bind to the same site on FKBP12 $(34,35)$. FKBP12 also binds to naturally occurring cellular targets (36) including three forms of intracellular calcium release channels, calcineurin, and the type I TGF- $\beta$ receptor $(16,33,37-40)$. The immunosuppressant drugs mimic hydrophobic domains found in the cellular targets of FKBP12. The presence of a serine for proline substitution at residue 10 in the rat form of FKBP12 would be expected to introduce a significant structural change at the amino terminus of the rat protein by removing a bend due to the proline residue at this position that is present in the human, rabbit, and murine forms of FKBP12. Thus, it is unlikely that the amino-terminal domain of FKBP12 is involved in mediating the antimigratory effects of the drug.

FKBP12 is physically associated with the skeletal muscle and cardiac ryanodine receptors $(37,38)$ and the inositol 1,4,5-trisphosphate receptor (39), all of which are calcium release channels located on the sarcoplasmic and endoplasmic reticuli. FKBP12 appears to stabilize the tetrameric structures of these large ion channel complexes and modulates channel gating (37). Moreover, both rapamycin and FK506 interfere with FKBP12's ability to stabilize calcium release channel structures resulting in leaky channels (37). Since the inhibition of migration was specific for rapamycin, and not FK506, it is unlikely that this effect involved modulation of calcium release channels resulting in altered calcium homeostasis.

Our results also demonstrate that administration of rapamycin in vivo inhibits the ability of SMC to migrate. Significantly, this inhibitory effect on migration persists for $2 \mathrm{wk}$ after exposure to rapamycin was stopped. This prolonged inhibitory effect on SMC migration suggests that a 1-wk treatment with oral rapamycin should reduce intimal hyperplasia, even if the stimulus associated with a vascular intervention lasts for up to 3 wk after the procedure.

\section{Acknowledgments}

We thank Valentin Fuster for reviewing this manuscript, Greg Wiederrecht for providing the carboxy terminal anti-FKBP12 antibody, Stuart Schreiber for helpful discussions, and Arthur Lee and Bin Liu for excellent technical assistance.

This work was supported by grants to A.R. Marks from the National Institutes of Health (RO1NS29814 and RO1HL56180), the American Heart Association (AHA), and the Muscular Dystrophy Association. A.R. Marks is a Bristol-Meyers Squibb Established Investigator of the American Heart Association. S.O. Marx is an AHA Clinician-Scientist awardee and a recipient of the Glorney-Räisbeck Fellowship from the NY Academy of Medicine. M. Poon is an AHA Clinician-Scientist awardee and a recipient of the Arthur Ross Scholarship in Cardiovascular Medicine. M.B. Taubman is a recipient of a Career Scientist award from the Irma T. Hirschl-Monique WeillCaulier Charitable Trusts. The sequence of the rat FKBP12 cDNA has been deposited in Genbank, BankIt67151 U69485, and the cDNA will be made available upon request to A.R. Marks.

\section{References}

1. Ross, R. 1993. The pathogenesis of atherosclerosis: a perspective for the 1990s. Nature (Lond.). 362:801-809.

2. Ip, J., V. Fuster, D. Israel, L. Badimon, J. Badimon, and J. Chesebro. 1991. The role of platelets, thrombin and hyperplasia in restenosis after coronary angioplasty. J. Am. Coll. Cardiol. 77B-88B.

3. Billingham, M. 1987. Cardiac transplant atherosclerosis. Transplantation Proc. 19 (Suppl. 5):19-25.

4. Casscells, W. 1992. Migration of smooth muscle and endothelial cells: critical events in restenosis. Circulation. 86:723-729.

5. Pauly, R.R., A. Passanti, C. Bilato, R. Monticone, L. Cheng, N. Papadopoulos, Y.A. Gluzband, L. Smith, C. Weinstein, E.G. Lakata, and M.T. Crow. 1994. Migration of cultured vascular smooth cells through a basement membrane barrier requires type IV collagenase activity and inhibited by cellular differentiation. Circ. Res. 75:41-54.

6. Clowes, A., and S.M. Schwartz. 1985. Significance of quiescent smooth muscle migration in the injured rat carotid artery. Circ. Res. 56:139-145.

7. Grotendorst, G.R., H.E.J. Seppa, H.K. Kleinman, and G.R. Martin. 1981 Attachment of smooth muscle cells to collagen and their migration toward platelet derived growth factor. Proc. Natl. Acad. Sci. USA. 78:3669-3672.

8. Ihnatowycz, I.O., P.D. Winocour, and S. Moore. 1981. A platelet-derived factor chemotatic for rabbit smooth muscle cells in culture. Artery. 9:316-317.

9. Ferns, G., E. Raines, K. Sprugel, A. Motani, M. Reidy, and R. Ross. 1991. Inhibition of neointimal smooth muscle accumulation after angioplasty by an antibody to PDGF. Science (Wash. DC). 253:1129-1132.

10. Jawien, A., D.F. Bowen-Pope, V. Lindner, S.M. Schwartz, and A.W. Clowes. 1992. Platelet-derived growth factor promotes smooth muscle migration and intimal thickening in a rat model of balloon angioplasty. J. Clin. Invest. 89:507-511.

11. Marx, S.O., T. Jayaraman, L.O. Go, and A.R. Marks. 1995. RapamycinFKBP inhibits cell cycle regulators of proliferation in vascular smooth muscle cells. Circ. Res. 76:412-417.

12. Nelson, P.A., J.A. Lippke, M.A. Murcko, S.L. Rosborough, and D.A. Peattie. 1991. cDNA encoding murine FK506-binding protein (FKBP): nucleotide and deduced amino acid sequences. Gene. 109:255-258.

13. Sewell, T.J., E. Lam, M.M. Martin, J. Leszyk, J. Weidner, J. Calaycay, P. Griffin, H. Williams, S. Hung, J. Cryan et al. 1994. Inhibition of calcineurin by a novel FK-506-binding protein. J. Biol. Chem. 269:21094-21102.

14. Standaert, R.F., A. Galat, G. Verdine, and S.L. Schreiber. 1990. Molecular cloning and overexpression of the human FK506-binding protein FKBP. Nature (Lond.). 346:671-674.

15. Hendrickson, B.A., W. Zhang, R.J. Craig, Y.-J. Jin, B.E. Bierer, S. Burakoff, and A.G. DiLella. 1993. Structural organization of the genes encoding human and murine FK506-binding protein (FKBP) 13 and comparison to FKBP1. Gene. 134:271-275.

16. Jayaraman, T., A.-M.B. Brillantes, A.P. Timerman, H. Erdjument-Bromage, S. Fleischer, P. Tempst, and A.R. Marks. 1992. FK506 binding protein associated with the calcium release channel (ryanodine receptor). J. Biol. Chem. 267:9474-9477.

17. Bierer, B., P.K. Somers, T.J. Wandless, S.J. Burakoff, and S.L. Schreiber. 1990. Probing immunosuppressant action with a nonnatural immunophilin ligand. Science (Wash. DC). 250:556-559.

18. Taubman, M.B., J.D. Marmur, C.-L. Rosenfield, A. Guha, S. Nichtberger, and Y. Nemerson. 1993. Agonist-mediated tissue factor expression in cultured vascular smooth muscle cells: role of $\mathrm{Ca}^{2+}$ mobilization and protein kinase C activation. J. Clin. Invest. 91:547-552. 
19. Bornfeldt, K.E., E.W. Raines, T. Nakano, L.M. Graves, E.G. Krebs, and R. Ross. 1994. Insulin-like growth factor-I and platelet-derived growth factor-BB induce directed migration of human arterial smooth muscle cells via signaling pathways that are distinct from those of proliferation. J. Clin. Invest. 93:1266-1274.

20. Sambrook, J., E.F. Fritsch, and T. Maniatis. 1989. Molecular Cloning: A Laboratory Manual. Cold Spring Harbor Laboratory, Cold Spring Harbor, NY. 709 pp.

21. Gregory, C., P. Huie, M. Billingham, and R. Morris. 1993. Rapamycin inhibits arterial intimal thickening caused by both alloimmune and mechanical injury. Transplantation. 55:1409-1418.

22. Brown, E., M. Albers, T. Shin, K. Ichikawa, C. Keith, W. Lane, and S. Schreiber. 1994. A mammalian protein targeted by G1-arresting rapamycinreceptor complex. Nature (Lond.). 369:756-758.

23. Sabatini, D., H. Erdjument-Bromage, M. Lui, P. Tempst, and S. Snyder. 1994. RAFT1: a mammalian protein that binds to FKBP12 in a rapamycindependent fashion and is homologous to yeast TORs. Cell. 78:35-43.

24. Kuo, C.J., J. Chung, D.F. Fiorentino, W.M. Flanagan, J. Blenis, and G.R. Crabtree. 1992. Rapamycin selectively inhibits interleukin-2 activation of p70 S6 kinase. Nature (Lond.). 358:70-73.

25. Price, D.J., J.R. Grove, V. Calvo, J. Avruch, and B.E. Bierer. 1992. Rapamycin-induced inhibition of the 70-kilodalton S6 protein kinase. Science (Wash. DC). 257:973-977.

26. Nourse, J., E. Firpo, M.W. Flanagan, M. Meyerson, K. Polyak, M.-H. Lee, J. Massagué, G.R. Crabtree, and J.M. Roberts. 1994. Rapamycin prevents IL-2-mediated elimination of the cyclin-CDK kinase inhibitor, p27Kip1. Nature (Lond.). 372:570-573.

27. Stossel, T. 1989. From signal to pseudopod. J. Biol. Chem. 264:1862118624

28. Pauly, R.R., C. Bilato, S.J. Sollott, R. Monticone, P.T. Kelly, E.G. Lakatta, and M.T. Crow. 1995. Role of calcium/calmodulin-dependent protein kinase II in the regulation of vascular smooth muscle cell migration. Circulation. 91:1107-1115.

29. Kundra, V., J.A. Escobedo, A. Kazlauskas, H.K. Kim, S.G. Rhee, L.T. Williams, and B.R. Zetter. 1994. Regulation of chemotaxis by the plateletderived growth factor receptor- $\beta$. Nature (Lond.). 367:474-476.
30. Shariff, A., and E.J. Luna. 1992. Diacylglycerol-stimulated formation of actin nucleation sites at plasma membranes. Science (Wash. DC). 256:245-247.

31. Rijken, P.J., W.J. Hage, P.M.P. van Begen en Henegouwen, A.J. Verkleij, and J. Boonstra. 1991. Epidermal growth factor induces actin organization of the actin microfilament system in human A431 cells. J. Cell Sci. 100:491-499.

32. Heitman, J., N.R. Movva, and M.N. Hall. 1991. Targets for cell cycle arrest by the immunosuppressant rapamycin in yeast. Science (Wash. DC). 253: 905-909.

33. Wang, T., P.K. Donahoe, and A.S. Zervos. 1994. Specific interaction of type I receptors of the TGF-beta family with the immunophilin FKBP-12. Science (Wash. DC). 265:674-676.

34. Michnick, S.W., M.K. Rosen, T.J. Wandless, M. Karplus, and S.L. Schreiber. 1991. Solution structure of FKBP, a rotamase enzyme and receptor for FK506 and rapamycin. Science (Wash. DC). 252:836-839.

35. Van Duyne, G.D., R.F. Standaert, P.A. Karplus, S.L. Schreiber, and J. Clardy. 1993. Atomic structures of the human immunophilin FKBP-12 complexes with FK506 and rapamycin. J. Mol. Biol. 229:105-124.

36. Marks, A.R. 1996. Cellular functions of immunophillins. Physiol. Rev. 76:631-649.

37. Brillantes, A.-M.B., K. Ondrias, A. Scott, E. Kobrinsky, E. Ondriasova, M.C. Moschella, T. Jayaraman, M. Landers, B.E. Ehrlich, and A.R. Marks. 1994. Stabilization of calcium release channel (ryanodine receptor) function by FK-506 binding protein. Cell. 77:513-523.

38. Timerman, A.P., T. Jayaraman, G. Wiederrecht, H. Onoue, A. Marks, and S. Fleischer. 1994. The ryanodine receptor from canine heart sarcoplasmic reticulum is associated with a novel FK-506 binding protein. BBRC. 198:701706.

39. Cameron, A.M., J.P. Steiner, D.M. Sabatini, A.I. Kaplin, L.D. Walensky, and S.H. Snyder. 1995. Immunophilin FK506 binding protein associated with inositol 1,4,5-trisphosphate receptor modulates calcium influx. Proc. Natl. Acad. Sci. USA. 92:1784-1788.

40. Cardenas, M.E., C. Hemenway, R.S. Muir, R. Ye, D. Fiorentino, and J. Heitman. 1995. Immunophilins interact with calcineurin in the absence of exogenous immunosuppressive ligands. EMBO (Eur. Mol. Biol. Organ.) J. 13:59445957. 